\title{
Evaluation Efficacy and Persistence of Some Volatile Plant Oils on Immature Stages of Galleria mellonella (L.)
}

\author{
Sawsan S. Moawad ${ }^{1} \&$ Ibrahim M. A. Ebadah ${ }^{1}$ \\ ${ }^{1}$ National Research Center, Cairo, Egypt \\ Correspondence: Sawsan S. Moawad, National Research Center, Cairo, Egypt. Tel: 20-011-1078-4181. E-mail: \\ abzs9999@yahoo.com
}

Received: September 9, 2021

Accepted: October 27, $2021 \quad$ Online Published: December 15, 2021

doi:10.5539/jas.v14n1p104

URL: https://doi.org/10.5539/jas.v14n1p104

\begin{abstract}
The Experiment was carried out to measure the effect of four natural plant oils (namely: Cinnamonium zeylanicum L., Syzygium aromatic L., Citrus aurantium amara, and Lavandula spica) on controlling the greater wax moth and their ability to persist. The methodology included collecting and rearing the greater wax moth under laboratory conditions to be able to isolate the target tested stages. The immature stages (eggs and larvae) of the experiment moth were exposed to fumes of tested oils $(50 \mu 1 / 500 \mathrm{ml})$ to calculate hatchability and mortality percentage. The results were clear that fumes of C. zeylanicum and S. aromatic were caused $100 \%$ unhatching eggs after zero time as the same recorded by comparable compound (paradix) and able to persist their effect at the closed and limited zone for 60 days. On another side, C. zeylanicum and $S$. aromat were affected on last larval instars and emerged adults. The accumulative effect was appeared in the case of treatment by $C$. zeylanicum which was caused sterility to emerged adults and reduced eggs deposition to zero. The data indicated that some natural product compounds could be used as an alternative way of control insect pests.
\end{abstract}

Keyword: volatile oils, fumes, eggs, larvae, greater wax moth

\section{Introduction}

The honeybee is mentioned in holly books as an example of a beneficial insect group and with the time the science was confirmed that they played an important role in increasing the yield of various crops (as pollinator) besides their useful produces such as propels pollen, royal jelly, bee wax, and honey. The honeybees infected by some pests such as the greater and lesser wax moth are a highly destructive insect that attacks and destroys beeswax combs especially those in storage and can cause substantial losses to combs, hive materials all over the world (Crane, 1990; NBN Atlas, 2017). After eggs are laid in the hive, the larvae burrow through the honeycombs and cause massive destruction, in addition to trapping emergent bees. This leads to the destruction of honeycombs and subsequent deterioration of the weakened colonies (Kwadha et al., 2017).

To prevent or manage infestations, cultivators are encouraged to maintain sanitary conditions for their bees, as it will keep the colony strong so they can keep G. mellonella out. Cracks and crevices should also be sealed so that adult G. mellonella cannot lay their eggs there. Combs should be replaced regularly and infested combs should be removed as soon as possible. Measures have been developed to prevent and manage infestations, but many have unresolved downsides. So many researchers were interested to suggest another alternative way to protect honeycomb from infestation. The fumigation technique was considered one of the successful methods in protecting honey hives. Recently, testing fumes of plant volatile oils was paid attention by many authors ( Sharaby et al., 2009; Moawad et al., 2015; Ursani et al., 2014; Moawad \& Sadek, 2018).

The target of the present work was to show the role of the volatility of some plant oil in protecting wax comb from $G$. mellonella and measure their persistence.

\section{Materials and Methods}

\subsection{Rearing Technique}

Females and males of the greater wax moth were collected from the infested honey wax combs, and then released in a plastic cups $(1000 \mathrm{ml})$ for mating and depositing eggs. The collected eggs were placed on other plastic cups till larvae hatched and then were feed on an artificial diet (according to Metwally, 2013) till 
pupation. The source of different G. mellonella stages for experiments were obtained from maintained culture after rearing on an artificial diet under the laboratory condition for two generations.

\subsection{Effect of Fumes of Tested Oils}

\subsubsection{Egg Stage}

The deposited eggs (age: $0-24 \mathrm{hr}$ ) and (48-72 hr) were collected and continuously exposed to tested oils (50 $\mu 1 / 500 \mathrm{ml})$ for interval time (0-10-20-30 and 60 days) to measure the residual efficacy and persistence index of tested oils on \% of unhatching eggs. The result of the experiment was compared with paradix (as the main insecticide which was used in controlling wax moths).

\subsubsection{Last Larval Stage}

Ten individuals of the last larval instar G. mellonella were kept in cups $(500 \mathrm{ml})$. Each cup was continuously exposed separately to fumes of the tested volatile oils $(50 \mu 1 / 500 \mathrm{ml})$ and check daily to calculate the percentage of larval mortality, pupation, emergence, abnormality, and the average number of deposited eggs per emerged female. Three replicates were carried out for each treatment.

\subsection{Sources of Tested Oils}

Clove oil (Syzygium aromatic L.) and cinnamon oil (Cinnamonium zeylanicum L.) were obtained from Sigma (Germany). While Bitter orange (Citrus aurantium Amara) and Lavander (Lavandula spica) were obtained from Haraz (Saudia Arabia)

\section{Results}

\subsection{Effect of Tested Oils on Egg Stage}

Table 1 clear that fumes of tested volatile oils especially C. zeylanicum and S. aromatic were caused $100 \%$ unhatching eggs after zero time as the same recorded by comparable compound (paradix) but the effects of the natural oils were reduced by the time till reached to 0.0 after 60 days while paradix effect was extended along 60 days. On other hand, fumes of $C$. aurantium were caused unhatched reached $67.8 \%$ (eggs ages $0-24 \mathrm{hr}$ ) and $37.5 \%$ (eggs ages $48-72 \mathrm{hr}$ ) after 0 times but their effect was reduced to zero after 20 days. So, the paradics was recorded the highest residual efficacy and persistence index follows by C. zeylanicum, S. aromat, and C. aurantium. 
Table 1. Persistence effect of some volatile oils on egg hatchability of greater wax moth

\begin{tabular}{|c|c|c|c|c|c|c|c|}
\hline \multirow{3}{*}{ Treatment } & \multirow{3}{*}{ Time of treatment (day) } & \multicolumn{6}{|c|}{ Egg stages } \\
\hline & & \multicolumn{2}{|c|}{$\%$ of egg un-hatching } & \multicolumn{2}{|c|}{ Residual efficiency (F/I) } & \multicolumn{2}{|c|}{$\begin{array}{l}\text { Persistence index } \\
\text { (F/I X days) }\end{array}$} \\
\hline & & $0-24 \mathrm{hr}$ & $48-72 \mathrm{hr}$ & $0-24 \mathrm{hr}$ & $48-72 \mathrm{hr}$ & $0-24 \mathrm{hr}$ & $48-72 \mathrm{hr}$ \\
\hline \multirow{6}{*}{ Cinnamonium zeylanicum } & 0 & $100^{\mathrm{I}}$ & $100^{\mathrm{I}}$ & \multirow{6}{*}{0.42} & \multirow{6}{*}{0.34} & \multirow{6}{*}{12.7} & \multirow{6}{*}{20.4} \\
\hline & 10 & 100 & 100 & & & & \\
\hline & 20 & 92.3 & 85.1 & & & & \\
\hline & 30 & $42.2^{\mathrm{F}}$ & 59 & & & & \\
\hline & 60 & 0.0 & $33.8^{\mathrm{F}}$ & & & & \\
\hline & Mean \% & 66.9 & 75.6 & & & & \\
\hline \multirow{6}{*}{ Syzygium aromatic } & 0 & $100^{\mathrm{I}}$ & $100^{\mathrm{I}}$ & \multirow{6}{*}{0.57} & \multirow{6}{*}{0.32} & \multirow{6}{*}{5.7} & \multirow{6}{*}{3.7} \\
\hline & 10 & $56.6^{\mathrm{F}}$ & $32.3^{\mathrm{F}}$ & & & & \\
\hline & 20 & 0.0 & 30.2 & & & & \\
\hline & 30 & 0.0 & 24 & & & & \\
\hline & 60 & 0.0 & 0.0 & & & & \\
\hline & Mean \% & 31.3 & 37.3 & & & & \\
\hline \multirow{6}{*}{ Citrus aurantium } & 0 & $67.8^{1}$ & $37.5 \mathrm{I}$ & \multirow{6}{*}{0.29} & \multirow{6}{*}{0.89} & \multirow{6}{*}{2.9} & \multirow{6}{*}{8.9} \\
\hline & 10 & $20.1^{\mathrm{F}}$ & $33.3^{\mathrm{F}}$ & & & & \\
\hline & 20 & 0.0 & 0.0 & & & & \\
\hline & 30 & 0.0 & 0.0 & & & & \\
\hline & 60 & 0.0 & 0.0 & & & & \\
\hline & Mean \% & 17.6 & 19.97 & & & & \\
\hline \multirow{6}{*}{ Lavandula spica } & 0 & 10.2 & 14.2 & \multirow{6}{*}{0.0} & \multirow{6}{*}{0.0} & \multirow{6}{*}{0.0} & \multirow{6}{*}{0.0} \\
\hline & 10 & 0.0 & 3.1 & & & & \\
\hline & 20 & 0.0 & 1.03 & & & & \\
\hline & 30 & 0.0 & 0.0 & & & & \\
\hline & 60 & 0.0 & 0.0 & & & & \\
\hline & Mean \% & 2.04 & 3.7 & & & & \\
\hline \multirow{6}{*}{ Paradix } & 0 & 100 & 100 & \multirow{6}{*}{1} & \multirow{6}{*}{1} & & \\
\hline & 10 & 100 & 100 & & & & \\
\hline & 20 & 100 & 100 & & & & \\
\hline & 30 & 100 & 100 & & & 60 & 60 \\
\hline & 60 & 100 & 100 & & & & \\
\hline & Mean \% & 100 & 100 & & & & \\
\hline
\end{tabular}

Note. $\mathrm{I}=$ initial effect; $\mathrm{F}$ = final effect.

\subsection{Effect on Last Larval Instar}

The data in Table 2 cleared that C. zeylanicum was caused the highest larval mortality (88\%), followed by $S$. aromat $(75 \%)$ compared to control $(0.0 \%)$. The pupal stage wasn't affected but in treatment, the percentage of emerged females was more than male compared to control. on another side, the accumulative effect was appeared in the case of treatment by C. zeylanicum which was caused sterility to emerged adults and reduced eggs deposition to zero. In addition to other treatments was caused a highly significant reduction in the mean number of deposited eggs compared to control. 
Table 2. Effect of tested oils on last larval stage of Galleria mellonella

\begin{tabular}{|c|c|c|c|c|c|}
\hline \multirow{2}{*}{ Investigation observation } & \multicolumn{5}{|c|}{ Tested oils } \\
\hline & Control & Cinnamonium zeylanicum & Syzygium aromatic & Citrus aurantium & Lavandula spica \\
\hline Larval mortality \% & 0.0 & 88 & 75 & 15 & 6 \\
\hline Pupation $\%$ & 100 & 12 & 25 & 85 & 94 \\
\hline Emergence $\%$ & 100 & 13.6 & 33.3 & 100 & 100 \\
\hline Male $\%$ & 51.72 & 42.11 & 40.7407 & 35.71 & 45.83 \\
\hline Female $\%$ & 48.28 & 57.89 & 59.26 & 60.71 & 54.17 \\
\hline no of eggs/female & $255.39^{\mathrm{a}}$ & $0^{\mathrm{d}}$ & $205.75^{\mathrm{c}}$ & $363.22^{\mathrm{a}}$ & $45.4^{\mathrm{c}}$ \\
\hline Abnormality \% & 0 & 0 & 0 & 3.57 & 0 \\
\hline Statistical analysis & \multicolumn{5}{|c|}{ L.S.D. $0.05=5.4$} \\
\hline
\end{tabular}

Note. Means with the same letters in vertical columns are not significantly different $(\mathrm{P}>0.05) .{ }^{*}$ significant at $(\mathrm{p}>0.05 ; * *$ highly significant at $(\mathrm{p}>0.01)$.

\section{Discussion}

The obtained results were clear that fumes of $C$. zeylanicum and $S$. aromatic could overcome the greater wax moth infestation for a long time especially in egg stages. Many researchers were spotted a light on the effect of volatile oils on different insect stages and confirmed their ability to reduced insect population.

These results agree with the observations of Owayss and Abd-Elgayed (2007) who found that methyl salicylatem formic acid, clove and basil oils were had ability to protect wax comb stored ordinarily in the apiary.

Moawad et al. (2015) improved that all stages of the greater wax moth were affected by fumes of clove and geranial oils. Moawad et al. (2013) found that clove, eugenol, and isoeugenol oils were caused a high reduction percentage of penetration and accumulative mortality of Tuta absoluta larvae and ovipositional deterrence reaction towards its' adult stage. Moawad and Al Gamdi (2018) who showed that fumes of S. aromaticum (L.) was caused a reduction in eggs hatchability of Oryzaephilus surinamensis (L.).

Moawad, and Ebadah, 2021 cleared that the most of fumes of volatile oils (especially, C. zeylanicum (L.), Geraniol, and S. aromaticum (L.) affected the different stages of Plodia interpunctella. They also noticed that the most of un-hatched eggs in the experiment had embryonic development that means the tested oils might be a hormonal or toxic effect.

The effect of fumes of volatile oils on immature stages of insects might be attributed to the chemical composition of tested oils which were affected on insect inhalation (Sharaby et al., 2009; Dawidar \& Hussien, 2010), or their toxicity on insect tissue (Moawad et al., 2013).

\section{Conclusion}

The present search was indicated that some natural product compounds could be used as an alternative way of control rather than synthesis chemical or introduced in integrated pest control programs as safe materials.

\section{Acknowlegements}

This research is funded by national research center, Cairo, Egypt.

\section{References}

Crane, E. (1990). Bees and Beekeeping, Science practice and World Resources. Heineman Professinal Publishing Ltd., Halley Court, Jordan Hills Oxford.

Dawidar, A., \& Hussien, K. (2010). Essential Oils, Composition, Photooxidation, Bioactivity (pp. 1-28). Osiris Bookstore, Cairo, Egypt.

Kwadha, C. A., Ong'amo, G. O., Ndegwa, P. N., Raina, S. K., \& Fombong, A. T. (2017). The Biology and Control of the Greater Wax Moth, Galleria mellonella. Insects., 8(2). https://doi.org/10.3390/insects 8020061

Metwally, H. M. (2013). Improving production and potency of bio-insecticide based on entompathogenic nematodes (p. 142, Ph.D. thesis, Faculty of Science, AIN Shams University, Egypt). 
Moawad, S. S., \& Al Gamdi, F. N. (2018). Efficacy of Some Botanical Volatile Oils on Protection Dry Date Palm from Oryzaephilus surinamensis L. Infestation. J. Entomol., 15(3), 106-113. https://oi.org/10.3923/ je.2018.106.113

Moawad, S. S., \& Ebadah, I. M. A. (2021). Assessment of some botanical oils impact on biology of Plodia interpunctella (Hübner) (Lepidoptera: Pyralidae). Wulfenia J., 28(3), 2-13. Retrieved from http://multidisciplinarywulfenia.org/auto/journals/published/1613566483_BgQTyl9.pdf

Moawad, S. S., \& Sadek, H. E. (2018). Evaluation of two eco friendly botanical oils on cotton leaf worm, Spodoptera littoralis (Boisd) (Lepidoptera/Noctuidae). Ann. Agric. Sci., 63, 141-44. https://doi.org/10.1016/ j.aoas.2018.09.002

Moawad, S. S., Ebadah, I. M. A., \& Mahmoud, Y. A., (2013). Biological and histological studies on the efficacy of some botanical and commercial oils on Tuta absoluta Meyrick (Lepidoptera: Gelechiidae). Egyptian Journal of Biological Pest Control, 23(2), 301-308.

Moawad, S. S., Elbehery, H., \& Ebadah, I. M. (2015). Effect of the volatile oils on some biological aspects of Galleria mellonella L. and its' parasitoid species, Bracon hebetor Say. Egyptian J. Biol. Pest Contr., 25, 603-607.

NBN Atlas. (2017). Galleria mellonella (Linnaeus, 1758): Wax Moth. NBN Atlas. Retrieved from https://species.nbnatlas.org/species/NHMSYS0000502701

Owayss, A. A., \& Abd-Elgay, A. A. (2007). Potential efficacy of certain plant volatile oils and chemicals aganist greater wax moth, Galleria mellonella L. (Lepidoptera: Pyralidae). Bull. Soc. Egypt, Econ. Ser., 33, 67-75.

Sharaby, H. A., Rahman, S., \& Moawad, S. (2009). Biological effects of some natural and chemical compounds on the potato tuber moth, Phthorimaea operculella Zell. (Lepidoptera: Gelechiidae). Saudi J. Biol. Sci., 16(1), 1-9. https://doi.org/10.1016/j.sjbs.2009.07.001

Ursani, T. J., Malik, S., Chandio, J. I., Palh, Z. A., Soomro, N. M., Lashari, K. H., ... Mastoi, G. M. (2014). Screening of biopesticides against insect pests of brinjal. Int. J. Emerging Trends Sci. Tech., 1, 918-31.

\section{Copyrights}

Copyright for this article is retained by the author(s), with first publication rights granted to the journal.

This is an open-access article distributed under the terms and conditions of the Creative Commons Attribution license (http://creativecommons.org/licenses/by/4.0/). 